\title{
13 Health Governance during the COVID-19 Pandemic
}

\author{
Reflections on Taiwan's Guest Worker Policy
}

\author{
Mei-Chun LIU
}

\begin{abstract}
Taiwan's government was quick to act against COVID-19 with a quarantine decree, mask mandates, detailed tracking of confirmed cases, and the nearly $100 \%$ coverage rate of universal health insurance. This approach proved successful during 2020. However, at the same time, Taiwan's 'guest worker policy' deprives migrant workers of the right to permanent residency/citizenship, freedom of employment, social security benefits, and residency arrangements. They lack access to health care and financial support, and they have faced wage cuts and dismissals during the COVID-19 pandemic, making them a vulnerable minority. This chapter argues that Taiwan needs to reconsider its 'divide and exclude' guest worker policy, not only for the sake of migrant workers themselves but also to safeguard public health.
\end{abstract}

Keywords: health governance, guest worker policy, Taiwan (Republic of China), health insurance, migrant labour, COVID-19

\section{Introduction}

The COVID-19 pandemic has brought the momentum of globalization to a near halt, causing unmeasurable ramifications in terms of economics, human rights, and social inequality. Taiwan's government was quick to act in tackling this unprecedented global health crisis. During the first year

\footnotetext{
Van der Veere, Anoma P., Florian Schneider, and Catherine Yuk-ping Lo (eds), Public Health in Asia during the COVID-19 Pandemic: Global Health Governance, Migrant Labour, and International Health Crises. Amsterdam, Amsterdam University Press 2022 DOI: 10.5117/9789463720977_CH13
} 
of the pandemic, its strategy proved successful, with only nine deaths and 909 confirmed cases before 30 January 2021.

The low infection rate achieved in Taiwan during this period can be attributed to various causes, such as widespread mask-wearing and an effective quarantine decree. The early success handling COVID-19 is also partly due to Taiwan's universal health insurance that covers everyone, including blue-collar migrant workers. In contrast to the benefits brought by this universal healthcare system, however, Taiwan also has a 'guest worker policy' that deprives migrant workers of the rights to permanent residency/citizenship, freedom of employment, and social security benefits, making them vulnerable during crises. This chapter both examines the successes Taiwan had dealing with COVID-19 during the first year of the pandemic and also looks at the ways that the pandemic has exposed the vulnerabilities of migrants in Taiwan. COVID-19 has revealed that migrants face disadvantages in access to health care and financial support, as seen in wage cuts and dismissals. The chapter argues that it is therefore time to reconsider the 'divide and exclude' nature of Taiwan's guest worker policy.

\section{Globalization and its Challenge to Public Health}

With proponents of globalization optimistically proclaiming the 'end of history' (Fukuyama 1992) and the benefits of a 'flat earth' (Friedman 2005), globalization seemed to herald a promising new world. However, as the so-called 'globalization' of the world has progressed, these prophesies have been turning into a bleaker picture. This is especially the case for those who have been denied a share in the new prosperity globalization has brought, something which is exacerbated by rising inequality among the northern and the southern hemispheres (Chomsky 2006, 2012; Stiglitz 2002, 2015). On the one hand, globalization has enhanced the free flow of people and capital, boosting the global economy. On the other hand, it has increasingly jeopardized state sovereignty, leaving nation-states subject to the consequences of heightened interconnectivity. This is something that has been made clear by the world's vulnerability to global pandemics.

Under conditions of increasing globalization, conflicts and turmoil have become more pronounced since the start of the new millennium with different regions hit by refugee crises and a series of new infectious diseases. Five new viruses have led to extensive human casualties over the past decade, namely $\mathrm{H} 1 \mathrm{~N}_{1}$ (2009), Polio (2014), Ebola in West Africa (2014), and Zika (2016) and Ebola in the Democratic Republic of Congo (2019). Each of these viruses was declared 
a Public Health Emergency of International Concern (PHEIC) by the World Health Organization (WHO). The devastating effect of virulent viruses has made global health governance an urgent issue on the international agenda in recent years, with calls for making it a joint global endeavour (Kickbusch 2016; Friedman and Lawrence 2017; Gostin, Moon, and Meier, 2020).

The COVID-19 pandemic, an unprecedented global crisis, has brought to the fore a pressing concern for the protection of fundamental human rights. In different countries, human rights have been jeopardized during the pandemic by the restriction of people's movement for health reasons, as well as a shortage of health care provisions. COVID-19 has devastated economies, livelihoods, and the way people interact with each other, meaning that concerted public health actions, both globally and locally, are now imperative.

\section{Migration and its Challenge to Global Health Governance}

The international community has been overwhelmed by the virulence and mutating adaptability of the COVID-19 virus, posing a real challenge to delivering effective, as well as coordinated, measures to ensure health safety for all. In one attempt to do so, the WHO launched the COVID-19 Solidarity Response Fund in partnership with the UN Foundation. This Fund is intended to collect donations and financially support public health initiatives seeking to contain the pandemic across the globe (WHO 2020). However, one question about the Fund, is whether it will recognize the plight of migrant workers in different countries. These migrant workers have been particularly hard-hit by the COVID-19 pandemic, often suffering mass lay-offs or wage cuts and thus facing hardships due to the global economic slow-down as well as lack of health protection.

The fact that migration is a significant public health issue and has pervasive global health implications has not yet received enough attention. Studies have shown that the abusive and exploitative treatment that many migrants encounter has led to a wide range of public health issues (Ottisova et al. 2016). COVID-19 has offered a watershed moment, prompting societies to re-examine the public health institutions and policy loopholes that have left those most marginalized even more destitute during the pandemic, especially with regard to access to health resources and information.

Amongst the Sustainable Development Goals of the UN, there is the goal of ensuring 'healthy lives' and promoting 'well-being for all at all ages' (United Nations 2020). However, even if this goal is largely being realized, 
disadvantaged populations still suffer from insufficient access to health services and lack the needed materials for personal protection as a result of discrimination, lack of access to health care services, and denial of welfare benefits (Kickbusch 2016). This is a reminder that even if a nation has excellent universal health insurance, this does not automatically guarantee equal health provision and safety for all unless marginalized segments of the population have received due attention.

In order to tackle the issues related to unequal health provision, a number of measures should be taken. As Zimmerman and Kiss (2017) suggest, preventive measures that address structural determinants (such as discrimination and constrained access to health care services) should be prioritized because of their enormous impact on migrants' health. It is crucial to have an inclusive decision-making mechanism through which migrants can have their voices heard. Looking at the case of Taiwan, the COVID-19 pandemic might be viewed as a disaster that can be turned into an opportunity by helping to expose the deficiencies in Taiwan's guest worker policy which follows the rule of 'dividing and excluding' that emerged from nationalism and discrimination against migrants. The use of this rule can be seen as detrimental not only to the migrants themselves, but to everyone living in Taiwanese society.

\section{Taiwan's 'Guest Worker Policy' in Danger of Breaching Human Rights}

In Taiwan today, the population of blue-collar migrants already outnumbers the population of Taiwan's officially recognized sixteen indigenous peoples. ${ }^{1}$ This is followed in size by marriage migrants totalling 565,299 persons, ${ }^{2}$ a significant sum considering Taiwan's population stands at 23,561,236 persons. ${ }^{3}$

1 Migrant workers include white-collar and blue-collar workers. Both are regulated through the Employment Service Law (1992), but receive differential treatment. White-collar migrant workers, mainly specialized/technical workers and language teachers, enjoy freedom of movement, choice of employers, and a duration of stay as long as their work permit is valid. All those rights are denied to the 713,454 blue-collar migrant workers (as compared to the 39,439 white-collar migrant workers, as reported by the end of April 2021).

2 Indicating migrants who enter Taiwan through marriage. Since the 1980s, men from lower social strata turned to Southeast Asian countries, mainly Vietnam, Indonesia, Thailand, and Philippines, in search for marriage partners. The annual number of marriage migrants has declined since 2004 .

3 Taiwan used to have four major ethnic groups with Fukienese as the largest, followed by mainlanders, Hakkanese and indigenous peoples, before the 1980s. Taiwan's census bureau 
Migrant workers are covered by Taiwan's highly renowned universal health insurance, which features low premiums, low co-pay, free access, and a nearly $100 \%$ coverage rate. However, the utilization rate of this insurance by migrants is minimal. This is due to several impeding features produced by Taiwan's guest worker policy. Instituted through the Employment Services Law of 1992, the migrant worker policy, often referred to as guest worker policy, guides the employment and management of migrant workers in Taiwan. This policy strictly confines blue collar migrant workers to predesignated employers and places of work even before entering Taiwan. If they leave their employers and start work elsewhere, they become illegal and undocumented, regardless of whether their reasons for leaving are legitimate or not. This policy allows employers to dismiss workers at will, often by sending migrants back to the brokers without worrying about legal consequences (Aspinwall 2020).

Although Taiwan has a high demand for migrant workers, its society has not been ready to accept them as part of the population (Wang 2011). Migrant workers are officially designated as complementary workers, not substitute workers. As a result, they can only sign fix-term temporary contracts which deprive them of the right to attain permanent residency, let alone citizenship (Tseng and Wang 2011). This is regardless of how long they have been working in Taiwan, with live-in domestic migrants allowed to work for a maximum of fourteen years and migrants working in factories and nursing homes for up to twelve years (Ministry of Labour 2018).

Migrant workers are, in practice, denied social welfare benefits, even if most are workers covered by health insurance and labour insurance, with the exception of live-in domestic migrant workers who only enjoy health insurance. Nevertheless, the benefits that migrant workers have from both insurances are not comparable with those that are enjoyed by locals, such as maternity benefits, unemployment benefits, and wage compensation for hospitalization due to occupational injuries as well as disease. ${ }^{4}$ This is

removed the question on ethnicity in 1990. Therefore, we can only estimate ethnic populations through sources such as the Council of Indigenous Peoples, the Hakka Affairs Council, the National Immigration Agency and the National Development Council, which all have their own surveys to monitor the population. An accurate estimate is beyond the scope of this chapter. The National Immigration Agency produces an annual statistical report on marriage migrants and work migrants, and the Council of Indigenous Peoples has their own survey.

4 Migrant workers are legally covered by both Universal Health Insurance and Labour Insurance, with the exception of domestic migrant workers who are covered by the former but not the latter. However, when it comes to the realization of those benefits promised by both insurances, blue-collar migrant workers have been disadvantaged due to their lack of information, and the complicated procedures required for filing claims, making it difficult to enjoy some of 
especially the case when they are claiming benefits for severe occupational injuries that require hospitalization and rehabilitation. In these cases, some employers have brokers who 'take back' injured migrants that have not medically recovered. These brokers will then send back the injured workers even before they are able to receive compensation from employers or their insurance benefits.

Living arrangements are another factor affecting the health of migrant workers. Migrant workers in Taiwan are often forced to accept dormitories prepared by brokers/agencies or employers. Employers set dormitory rules in order to effectively monitor and control workers, thus limiting migrants' freedom of movement outside factories and dormitories (Turton 2021). Living in the dormitories also means that migrants have to share fully packed rooms, bathrooms, and toilets (Everington 2018). These kinds of dwelling arrangements are dangerous to live in and make workers more susceptible to infectious diseases (Timmerman 2020). The outbreak of COVID-19 among migrant workers in Singapore in similar conditions exemplifies the health risks associated with close-quarter living conditions (Reuters 2020; Yi et al. 2020).

Another health risk for migrant workers lies in their reluctance to take sick leave for fear of wage loss and the risk of endangering possible contract renewal in the future. This unwillingness of migrant workers puts them at greater health risk, and can lead to unknown outbreaks (Wang et al. 2020; Aspinwall 2020). Moreover, it is difficult for undocumented migrant workers to seek medical help for fear of exposure and deportation. Another reason for their reluctance to seek medical help is financial, as they have to bear the full cost of medical expenses once they become undocumented, which also means losing their health insurance coverage. ${ }^{5}$

Migrant workers leave their employment and become undocumented for a number of different reasons. Migrant workers might seek to get

the benefits. In reality, for example, if female migrant workers get pregnant, it is unlikely that they are able to work until their due date without being dismissed by employers. Therefore, if pregnancy does occur, most of them choose to return to their home country, file a claim from their country of origin, or flee and work as an undocumented migrant in Taiwan.

5 According to Taiwan's migrant worker policy, employers have to provide National Health Insurance to migrant workers working in factories and households. However, once they flee, they lose their insurance. Taiwan's national health insurance is renowned for its fairly low premium (5.17\% of monthly income of which employers are obliged to pay $60 \%$, workers pay $30 \%$, and the government pays $10 \%$ ). It is also known for its extremely low fixed co-pay (about US $\$ 1.7$ for every clinic visit, US $\$ 3.3$ for every visit to a regional hospital, and US $\$ 5.7$ for a visit to a medical centre). Medical expenses will be fully covered by National Health Insurance Bureau. If something happens to them after they have become undocumented, workers may be liable for sizeable medical costs depending on the level of treatment required. 
away from unbearable working conditions, sexual assault, or inhumane treatment. Debt-ridden migrant workers have previously fled to avoid repatriation when their contracts were prematurely terminated due to the death of care recipients, plant closure, or mass redundancy. This form of contract termination invited a wave of criticism. As a result, the guest worker policy has recently undergone changes to allow migrants to seek new employment within a limited period. This is under the condition that the termination of their contract is not their fault. However, in such cases brokers are often inactive due to a lack of financial incentives to help migrants in their job search. Brokers frequently resort to regulatory violations by sending workers back home (Lan 2006; Hsia 2005, 343-344; $\mathrm{Gu}$ 2013, 96).

Migrant workers also tend to owe large amounts of debt to brokers in order to land jobs in Taiwan. This means that they have to work longer hours to earn enough to pay back these loans. This debt burden has been another reason that migrants flee from their employment positions and become undocumented (Olive 2020; Fleeing Migrants 2012). ${ }^{6}$ Once this happens, the government loses track of the migrants and is unable to receive their periodic health reports. A special immigration task force is then charged with hunting them down. This can force the workers to go into hiding. Critics from academia and human rights organizations have been vocal about the inadequacy of current regulations (Hsiao 2020).

In summary, the current guest worker policy restricts the mobility of migrants and their freedom of occupation. It therefore renders the power relations between migrants and employers extremely imbalanced, to the detriment of the migrants. This is what Tan (2014) describes as a 'governmentality of exclusion'. In his study of Singaporean society, he explains that it is the whole institutional apparatus that discriminates against those deemed 'less worthy' and unsuitable for inclusion. This applies to Taiwan as well. The stringent residency policy, denial of the freedom of occupation, as well as limited mobility, together function to drive migrant workers to leave their legal but much constrained employment, and become undocumented. When migrants are forced to become undocumented, the health risks borne by migrant workers increase. The exclusion of undocumented migrant workers from the universal health insurance system thus endangers the whole population.

6 Fleeing Migrants is a collection of 25 stories told by undocumented migrants in Taiwan. As has been discussed here, there are various reasons for them fleeing their employment, with debt burden being the most pressing. The original publication is in Chinese. 


\section{Tackling COVID-19 - Protective Measures and Remedies for Migrants}

The Taiwanese government was quick to take action when the COVID-19 pandemic emerged at the start of 2020. It immediately implemented thermal imaging at the border. It mobilized factories for the production of masks and coordinated health-insurance-contracted pharmacies and convenience stores to facilitate access to masks. It banned mass gatherings and suspended businesses such as nightclubs where social distancing was not possible. It also implemented mandatory wearing of masks in cinemas, department stores, hospitals, post offices, banks, and on public transportation (Yip 2020). Schools and offices also took preventive measures, such as restricted entry and placing thermal imaging cameras at entrances. Flights were reduced, or suspended, in accordance with the development of the pandemic in different countries or regions (Ministry of Foreign Affairs 2021). The government also implemented a fourteen-day quarantine measure for everyone coming from abroad.

These measures can partly explain why, during the first year of the COVID-19 pandemic, Taiwan saw very low infection rates when compared to other countries around the world. However, Taiwan's success in 2020 is not a guarantee for sustained success. Since April 2021 new variants of the COVID-19 virus have started spreading, resulting in 14,157 new confirmed cases and 575 deaths by 23 June 2021. The new virus outbreak has hit eight technology plants, leading to cluster infections among migrant workers, 400 being confirmed by 21 June 2021 (Huang 2021).

Although the clustered spread of COVID-19 among hundreds of migrant workers in Singapore at the end of March 2020 forced the Taiwanese government to reconsider their policies in order to offer assistance to migrant workers, 7 the issue of clustered living conditions did not receive ample attention, eventually leading to the aforementioned outbreak in 2021.

In order to reduce cross-border movement, migrant workers were also encouraged to stay in Taiwan and renew their contracts or take new placements. They were given a transportation subsidy to compensate for the delay or cancelation of their annual leave. Employers were also encouraged to apply for the extension of permits for migrants who had reached the maximum

7 This includes providing information about the pandemic at migrant service centres stationed at the airport, installing a hotline, establishing a multi-lingual website aimed at migrants, and using social media, pamphlets, as well as flyers to disseminate information in a bid to reach Taiwan's migrant populations (Workforce Development Agency 2020). 
duration of stay (Ministry of Labor 2020). They were asked to apply for shortterm employment permits of three months or six months for those migrant workers with contracts due to end. They were also encouraged to release migrant workers to other employers if there was a slowdown in business.

The government also put in place a measure to cover the hospital expenses incurred by infected migrant workers to encourage these workers to seek medical attention without worrying about the possible financial burden. Wage loss due to quarantine measures has been compensated by the government at NT $\$ 1000$ per day (approximately US $\$ 35$ ) when employers have not paid this (Yang 2020). Meanwhile, the government has also instructed that quarantine fees have to be paid by employers or agencies. It is forbidden for these fees to be transferred to migrant workers, with employers/agencies being fined if they attempt to do so (Everington 2020).

The government migrant worker policy has undergone several changes throughout the COVID-19 pandemic. Home quarantine applied to all incoming migrant workers as early as 19 March 2020. However, as the pandemic escalated, newly arrived live-in domestic migrant workers and factory migrant workers with re-entry permits were required to undergo centralized quarantine, while newly arrived factory migrant workers were subject to employer-provided home quarantines starting from 27 March 2020.

As the pandemic continued to escalate in Indonesia by the end of 2020, the government's policy was adjusted to include a temporary ban on all Indonesian workers (Lee 2020; Taiwan Centres for Disease Control 2020). Due to a growing number of confirmed cases and a rising death toll, a more stringent policy was issued on 19 May 2021 to ban all visa applications in accordance with stricter border control (Bureau of Consular Affairs 2021).

In order to encourage undocumented migrant workers to come out of hiding and abide by the preventative health measures, the National Immigration Bureau has adopted a three-month amnesty policy that exempts them from the confinement, re-entry ban, and fine that normally would apply when workers are arrested. In addition, the government has offered undocumented migrant workers a free anti-virus taxi service to and from COVID-19 testing centres, quarantine checks, and medication in order to prevent new infections from spreading. ${ }^{8}$ During this three-month amnesty period, nearly 8000 workers reported to the government (Lo 2020; National Immigration Agency 2020).

8 The government recruits and contracts the so-called 'anti-virus taxi' to offer migrant workers a free service that allows them to use a safe method of transport, in contrast to using regular transportation methods through which the virus might spread. 
The Taiwanese government also initially demanded that migrant workers on fishing vessels underwent a fourteen-day quarantine on their vessels. This rule also applied to those who have a low risk of contracting the virus, such as workers who have not anchored in other nations, have not interacted with other ships, have not changed crew members, and have not been inspected by foreign officials in the 30 days prior to their return to Taiwan. These rules were later tightened, requiring compulsory on-board health management of crew members who did not go ashore, if the ship was to set sail again within fourteen days. However, if crew members leave their ship and enter the community, the rules require either a 'one crew member one room' version of quarantine on the ship, or a hotel quarantine for fourteen days.

Eleven security posts were set up in three different cities to provide help and to monitor deep sea fishing vessels. The government has also provided masks to fishing associations and organizations of ship owners, through which crews can purchase them. Those undergoing the 'one crew member one room' quarantine also receive a pandemic protection bag that contains masks, a temperature recording card, sanitizer, towels, and a toothbrush. Ship owners receive a subsidy of $\mathrm{NT} \$ 1500$ per crew member per day (approximately US\$39) if they are quarantined on this basis (Fisheries Agency 2020).

During the first stage of the COVID-19 pandemic these measures aimed at migrant workers in Taiwan proved relatively successful, resulting in a low rate of infections and confirmed cases related to migrant workers.

\section{Taiwan's Guest Worker Policy: Ready for an Overhaul?}

After the first stage of the COVID-19 pandemic appeared to subside, Taiwan was quick in seeing business resume, schools open, and people getting back to their daily routines. Nevertheless, the number of employers who have put their employees on unpaid leave or have dismissed these employees in large numbers has hit a record high. Migrants are covered by labour insurance but are denied unemployment benefits, unlike their Taiwanese counterparts who are entitled to these benefits. Furthermore, migrant workers are also not entitled to severance pay because their labour contracts exclude this right. This means that, for some migrant workers, even though they have been able to survive the pandemic, they are likely to be in great debt as a result of having been placed on unpaid leave or having been dismissed. Many of these migrant workers might be described as being virtually invisible to 
policy makers, who continue to ignore the predicament of migrant workers due to the 'divide and exclude' principle that characterises Taiwan's guest worker policy.

Although Taiwan is a signatory of five major human rights conventions, these conditions have persisted. Taiwan has notably not signed the International Convention on the Protection of the Rights of All Migrant Workers and Members of Their Families. It can be argued that the key to improving Taiwan's human rights record lies in the way workers' basic human rights are protected, such as the freedom of occupation, freedom of movement, a right to family reunion, equal rights to employment and justice, and permanent residency. It is therefore time for Taiwan to transform its guest worker policy, a policy that is still used to structurally exploit migrant workers' vulnerability by depriving them of their labour rights.

\section{Looking Ahead: Inclusiveness and Solidarity}

The unprecedented global health crisis sparked by the COVID-19 pandemic has exposed the exclusionary shortcomings of Taiwan's guest worker policy. The COVID-19 pandemic has hit those most marginalized the hardest and has disenfranchised migrant workers, who have already long been excluded from the Taiwanese government's worker protections. The way in which Taiwan's guest worker policy deprives migrant workers of certain rights exemplifies how, in different countries, an 'us vs. others' mentality can prevent fair policy and impede global public health challenges in an era of globalization.

As Kickbusch (2016) argues, a paradigm shift is necessary in global health governance, as health governance has deepened rising inequalities. Any country that withholds health as a basic human right, especially to migrants, will be trapped in an ever-worsening health dilemma. Global health governance therefore requires international solidarity.

This pandemic offers a rare opportunity to re-examine what has been achieved in global health governance up until now, and what is left to be amended after the pandemic is over. Normative principles need to be established that require the international community to recognize the importance of committing to inclusiveness, and to incentivize governments to take concerted action so as to include non-state actors that deserve more attention. Ulrich Beck (2011) used the concept of the 'cosmopolitan imperative' to describe the urgency that modern societies face in addressing emerging global risks that cannot be confined in space or time. The same 
reflection also applies to any society where discrimination, prejudice, and exclusionary policies do no justice to those most vulnerable. The safety of those most marginalized matters significantly when public health is concerned. Therefore, the existing structural inequity of health governance demands a close review in order to safeguard all.

\section{References}

Aspinwall, Nick. 2020. 'Taiwan Accused of Failing to Protect Medical Rights of Southeast Asian Workers.' The Diplomat, 14 November. Accessed 1 January 2021. https://thediplomat.com/2020/11/taiwan-accused-of-failing-to-protect-medicalrights-of-southeast-asian-workers/.

Beck, Ulrich. 2011. 'Cosmopolitanism as Imagined Communities of Global Risk.' American Behavioral Scientist vol. 55, no. 10: 1346-1361. https://doi. org/10.1177\%2Fooo2764211409739.

Bureau of Consular Affairs. 2021. 'Entry Restrictions for Foreigners to Taiwan in Response to COVID-19 Outbreak.' Accessed 22 June 2021. https://www.boca. gov.tw/cp-220-5081-co6dc-2.html.

Chomsky, Noam. 2006. Failed States: The Abuse of Power and the Assault on Democracy. New York: Metropolitan Books.

-. Occupy. 2012. London: Penguin Books.

Everington, Keoni. 2020. 'Taiwanese Employers Who Dock Migrant Worker Wages Can Face NT\$30o,00o fine.' Taiwan News, 18 August. Accessed 1 January 2021. https://www.taiwannews.com.tw/en/news/3989715.

-. 2018. 'New Taipei officials investigate overcrowding after Vietnamese worker protest.' Taiwan News, 25 April. Accessed 1 January 2021. https://www.taiwannews.com.tw/en/news/3413933

Fisheries Agency. 2020. Regulations on Offshore Home Quarantine of Fishing Crew and Subsidy on Inspection as Well As Testing. 7 August. Accessed 1 January 2021. https://www.coa.gov.tw/COVID_19/index.php?theme=ws\&id=2511058.

Fleeing Migrants. 2012. Fleeing: Our Formosa, Their Imprisonment. Taipei: China Times Publishing Co.

Friedman, Eric A., and Lawrence O. Gostin. 2017. 'The Framework Convention on Global Health: A Call for Leadership from the Global Health Trio.' Health Affairs: Global Health Policy, 12 January. https://www.healthaffairs.org/do/10.1377/ hblog20170112.058262/full.

Gostin, Lawrence O., Suerie Moon, and Benjamin Mason Meier. 2020. 'Reimagining Global Health Governance in the Age of COVID-19.' American Journal of Public Health vol. 110, no.11:1615-1619. 
Gu, Yu-Ling. 2013. 'A Distorted “Semi-liberal Market of Migrant Workers” in Taiwan.' Taiwan Human Rights Journal vol 2, no.2: 93-112.

Hsia, Hsiao-Chuan. 2005. 'Taiwan's Immigrants and Migrant Workers Under Globalization.' In Taiwan's Social Problems, Li-Yun Chang and Hai-Yuan Chu (eds.): 328-367. Kaohsiung: Chuliu Book Co.

Hsiao, Sherry. 'Migrant Workers, Rights Groups Protest in Taipei.' Taipei Times, 14 December. Accessed 13 February 2021. https://www.taipeitimes.com/News/ taiwan/archives/2020/12/14/2003748684.

Huang, Tzu-ti. 2021. 'Migrant Workers in Taiwan's Miaoli Complain About Lousy Dorm Environment.' Taiwan News, 21 June. Accessed 22 June 2021. https://www. taiwannews.com.tw/en/news/4228624.

Kickbusch, Ilona. 2016. 'Global Health Governance Challenges 2016 - Are We Ready?' International Journal of Health Policy and Management vol. 5 , no. 6: 349-353. https://dx.doi.org/10.15171/ijhpm.2016.27.

Lan, Pei-chia. 2006. 'Legal Servitude and Free Illegality: Control and Exit of Migrant Workers.' Taiwan: A Radical Quarterly in Social Studies vol. 64: 107-150.

Lee, I-Chia. 2020. 'Indonesian Workers Face Temporary Ban.' Taipei Times, 1 December. Accessed 22 June 2021. https://www.taipeitimes.com/News/front/ archives/2020/12/01/2003747880.

Lim, Emerson. 2021. 'Migrant Workers Call for Legal Protections in Women's Day Rally.' Focus Taiwan, 8 March. Accessed 25 March 2021. https://focustaiwan. tw/society/202103080019.

Lo, Ping-San. 2020. 'Amnesty to Undocumented Migrant Workers to Amend AntiCovid19 Loopholes.' Apple Daily, 11 December. Accessed 29 March 2021. https:// tw.appledaily.com/forum/20201211/SSSK43GEWRGF5JQXI7I2SCTYZ4/.

Ministry of Foreign Affairs (MOFA). 2021. 'Entry Restrictions for Foreigners to Taiwan in Response to COVID-19 Outbreak.' Bureau of Consular Affairs, Ministry of Foreign Affairs, Republic of China (Taiwan). Last updated 8 February 2021. Accessed 13 February 2021. https://www.boca.gov.tw/cp-220-5081-co6dc-2. html.

Ministry of Labor. 2018. Employment Service Act. Last amended 28 November 2018. https://law.moj.gov.tw/Eng/LawClass/LawAll.aspx?PCode=Noogooo1.

- 2020. 'The Epidemic Situation in the Country of Origin of Migrant Workers Ras Risen to Level 3, and the Ministry of Labor Has Introduced Measures to Strengthen Epidemic Prevention Management.' https://www.mol.gov.tw/ announcement/2099/44880/.

National Immigration Agency. 2020. 'Practices on Addressing Challenge from Overstaying Migrants during Anti-Covid-19.' Internal Report Presented at Meeting of Migrant Workers' Human Rights Task Force Held at Ministry of Labor. 8 October. 
Oliver, Jeremy. 2020. 'Breaking the Vicious Cycle for Taiwan's Economic Migrants.' Taiwan Business Topics, 8 August. Accessed 1 January 2021. https://topics.amcham.com.tw/2020/o8/taiwans-economic-migrants/.

Ottisova, L., S. Hemmings, L. Howard, C. Zimmerman, and S. Oram. 2016. 'Prevalence and Risk of Violence and the Mental, Physical, and Sexual Health Problems Associated with Human Trafficking: An Updated Systematic Review.' Epidemiology and Psychiatric Sciences vol. 25, no. 4:317-341. https://doi.org/10.1017/ s2045796016000135.

Stiglitz, Joseph E. 2002. Globalization and its Discontents. New York: W.W. Norton \& Company.

-. 2015. The Great Divide: Unequal Societies and What We Can Do about Them. New York: W.W. Norton \& Company.

Taiwan Centers for Disease Control. 2020. 'Taiwan will Continue Suspending Entry of Indonesian Migrant Workers and will Lift the Measure Depending on Coronavirus Situation in Indonesia.' Accessed 22 June 2021. https://www.cdc. gov.tw/En/Bulletin/Detail/AbegjzXzg3mAAGkooTgVeA?typeid=158.

Timmerman, Antonia. 2020. 'In Taiwan's 'Container Houses' for Migrant Workers, Coronavirus Not the Only Health Risk.' South China Morning Post, 26 April. Accessed 13 February 2021. https://www.scmp.com/week-asia/people/article/3081227/ taiwans-container-houses-migrant-workers-coronavirus-not-only.

Turton, Michael. 2021. 'Notes from Central Taiwan: Everyday Life As the 'Other'.' Taipei Times, 1 February. Accessed 25 February 2021. https://www.taipeitimes. com/News/feat/archives/2021/02/01/2003751553.

United Nations. 2020. 'Ensure Healthy Lives and Promote Well-being for All at All Ages.' Department of Economic and Social Affairs, Sustainable Development. Accessed 13 February 2021. https://sdgs.un.org/goals/goal3.

Wang, Hong-Zen. 2011. 'Immigration Trends and Policy Changes in Taiwan.' Asian and Pacific Migration Journal vol. 2o, no. 2: 169-194. https://doi.org/10.1177\% 2Fo11719681102000203.

Wang, Hong-zen, Pei-chia Lan, Yen-fen Tseng, Chia-ling Wu, and Chiung-chih Chen. 2020. 'Reaching out to Undocumented Workers is Necessary to Contain COVID-19 Outbreak.' Commonwealth Magazine. Accessed 25 February 2021. https://english.cw.com.tw/article/article.action?id=2667

Workforce Development Agency, Ministry of Labor. 2020. 'Covid-19 Employment Guidelines: Migrant Workers Precautions for Work, life, and Going out Management.' 24 April. Last revised 7 May 2020. https://fwas.wda.gov.tw/upload/ download/agb47afa24c43407d27de45f408cd335611fab29.pdf.

World Health Organization (WHO). 2020. 'COVID-19 Solidarity Response Fund.' https://www.who.int/emergencies/diseases/novel-coronavirus-2019/donate. 
Yang, Sophia. 2020. 'Taiwan Employers, Brokers Must Cover Quarantine Fees for Migrant Workers.' Taiwan News, 27 November. Accessed 25 February 2021. https://www.taiwannews.com.tw/en/news/4063088.

Yang, Wen San. 2014. A Study on Planning Ethnic Statistics Project in Taiwan. National Development Council. Accessed 21 March 2021. https://ws.ndc.gov.tw/ Download.ashx?u=LzAwMSghZGipbmlzdHJhdGgyLzEwL_JlbGZpbGUvNjE5 MC8xNTUyNi8wMDYxMjUzXzEucGRm\&n=5peP576k57Wx6KiILnBkZg\%3D $\%{ }_{3}$ D\&icon=.pdf.

Yi, Huso, Shu Tian Ng, Aysha Farwin, Amanda Pei Ting Low, Cheng Mun Chang, and Jeremy Lim. 2020. 'Health Equity Considerations in COVID-19: Geospatial Network Analysis of the COVID-19 Outbreak in the Migrant Population in Singapore.' Journal of Travel Medicine vol. 28, no. 2 (March): taaa159. https:// doi.org/10.1093/jtm/taaa159.

Yip, Hilton. 2020. 'Fear of China Made Taiwan a Coronavirus Success Story.' Foreign Policy, 16 March. Accessed 13 February 2021. https://foreignpolicy.com/2020/03/16/ taiwan-china-fear-coronavirus-success/.

Zimmerman, Cathy and Ligia Kiss. 2017. 'Human Trafficking and Exploitation: A Global Health Concern.' PLoS Medicine vol. 14, no.11 (2017): e1002437. https://doi. org/10.1371/journal.pmed.1002437.

\section{About the Author}

Mei-Chun LIU is a Professor at the Institute for Labor Research, School of Social Science, National Chengchi University, Taipei, Taiwan. She earned her PhD in Sociology at the University of Southern California, US. She is currently chairperson of the Taiwan Public Health Promotion Association, a former chairperson of the Taiwan Higher Education Union and the Taiwan Health Reform Foundation, and a committee member of the New Immigrants Development Fund. Between 2016 and 2020, she served as a member of the Human Rights Committee of the Presidential Office. 
